\title{
Corporate Social Responsibility in the Context of the Institutional Approach
}

\author{
E. Bakanova \\ University of Technology and Design, S-Petersburg, 191186, Russian Federation \\ *Corresponding Author: bakanova.spb@mail.ru
}

Copyright $@ 2014$ Horizon Research Publishing All rights reserved.

\begin{abstract}
The article describes the main stages of corporate social responsibility in the RF. The specific features of the Russian model of CSR are characterized. The author gives his view on trends of modern development of CSR practices of Russian companies.
\end{abstract}

\section{Keywords Corporate Social Responsibility, Stakeholder, Institutional Matrix}

\section{Introduction}

In conditions of globalization of world economy the role of socially responsible practices in the activities of the companies' increases. With no doubt, the financial crisis brings some elements of instability in the companies' social behavior. But, however, it can be supposed that a government, business and civil society partnership in the sphere of social policy will be developed in future too.

Corporate social responsibility practice based on the Anglo-American tradition of philanthropy and charitable activities of the business, therefore the modern comprehension of social responsibility of business is much wider. Under the definition of the World Bank, CSR combines some kinds of policies and business activities connected with main stakeholders and ethical values which take into consideration of the local community's interests and interests of social environment.

This approach is becoming more and more popular in Russia. It can be confirmed for example by definition Russian Association of Managers definition. According to this definition, «stakeholders are individuals, organizations or communities involved to a company activity directly or indirectly».

\section{Hypotheses}

Two hypotheses were set up during the research. The first one: Corporate social responsibility is a sphere of interaction of three social institutes. These institutes are business, state and civil society. Their activity is mediated by aggregated reciprocal socio-economical expectations. Here these expectations are represented as a matrix which is named "An institutional matrix" (fig. 1). The second hypothesis: An asymmetry of the institutional matrix takes place within interaction of members of corporate social responsibility this asymmetry is the strongest at the Business-Civil society line.

\begin{tabular}{|c|c|c|c|}
\hline & State & Business & Civil society \\
\hline State & & $\begin{array}{l}\text { Implementation of fiscal and other } \\
\text { institutional and economic commitments. } \\
\text { Health and safety at work of staff. } \\
\text { Community development. } \\
\text { Responsible business practices. }\end{array}$ & $\begin{array}{l}\text { Civil examination of social projects. } \\
\text { Monitoring of partnership projects. } \\
\text { Extra budgetary resources in the } \\
\text { social sector. }\end{array}$ \\
\hline Business & $\begin{array}{l}\text { Legislative Environment. } \\
\text { Implementation of the State's social functions. } \\
\text { Tax preferences. } \\
\text { Formation mechanisms of social recognition of } \\
\text { the social activity of business. }\end{array}$ & & $\begin{array}{l}\text { Participation in regional and/or } \\
\text { corporate social programs. } \\
\text { Interaction in defending the interests } \\
\text { of local communities. Carrying } \\
\text { public PR-campaigns. }\end{array}$ \\
\hline $\begin{array}{l}\text { Civil } \\
\text { society }\end{array}$ & $\begin{array}{l}\text { Regulatory and legal framework. } \\
\text { Tax preferences. } \\
\text { Establish mechanisms for funding of civil } \\
\text { initiatives. } \\
\text { Elimination of monopoly in decision-making. }\end{array}$ & $\begin{array}{l}\text { The transparency of social reporting } \\
\text { sponsorship. } \\
\text { Integrating public expectations in business. } \\
\text { Expert consulting. Contribution to the } \\
\text { development of civil society through } \\
\text { partnerships of local community } \\
\text { development. }\end{array}$ & \\
\hline
\end{tabular}

Figure 1. Institutional Matrix 


\section{Research Methods}

In order to examine the first hypothesis the author analysed scientific books [1-8] and also some articles published in Russian scientific journals. Contents of a scientific research "Social responsibility of Russian banks in 2013" by Artisan Group Public Relations were used to examine the second hypothesis.

\section{Results}

Nowadays Russian banking sphere is more conservative about corporate social activity in comparison with resent time. More than $80 \%$ of respondents noticed that interests of bank clients and stuff are in priority definitely. It's necessary to mention that such a position of Russian banks contradicts the main regulations of Russian standard IC CSR-26000-2011 "Social Responsibility of the Organization. Requirements", which is based on an international standard ISO 26000. Due to these documents corporate social responsibility includes a support of local communities in spite of the fact that these communities are outer stakeholders.

Corporate social responsibility itself (as a separate part of a bank activity) is important for $11 \%$ of Russian banks only. Banks consider an activity in this sphere as a result of a balance of main stakeholders' interest and as a kind of a bank reaction for society expectation. 32\% of respondents say they use corporate social activity as an instrument for solving of HR-problems of their organizations.

$8 \%$ of respondents think that an activity in a corporate social responsibility sphere is an important part of a credit organization marketing strategy. Other respondents don't have any clear idea about a place of corporate social responsibility in bank activity.

The prevailing point of view in Russian bank community is one that corporate social activity provides obvious advantages in business and better reputation to a credit organization in a case when the main objects of this activity are bank clients and staff. $9 \%$ of respondents declare that social activity of a bank, being concentrated on investors and partners, has an increasing of loaning as the main goal. 5\% think that corporate social activity helps to make contacts with government organizations easier and more comfortable. $4 \%$ of respondents don't see any difference in interests of different stakeholders' groups.

The financial support of a sphere of high education and increasing of a population financial literacy are the main direction of a social activity of Russian banks. More than $60 \%$ of Russian credit organizations practice these two kinds of activity. The second important direction of corporate social responsibility in Russian bank sphere is projects medicine and health service. It is important for $21 \%$ of Russian banks. The main forms of corporate activity in this field are donations for buying medicine which are necessary for victims of natural disasters ( $40 \%$ of respondents), voluntary blood donation (34\%) and common projects with pharmaceutical firms $(16 \%)$. The third direction of corporate social responsibility is projects in environmental protection (more than 13\%). 9\% of Russian banks support different cultural projects but only $4 \%$ of respondents think this sphere is a priority in their social activity.

\section{Discussion}

According to stakeholders approach Corporate Social Responsibility can be considered as a system of socio-economic relations not only about execution of business obligations under the law, but also about extra obligations which business assume Corporate Social Responsibility involves the integration of international principles and specific requirements to the business. In Russia a document of such level is Social Charter of Russian business, which takes into modern corporate practices and the latest global and domestic trends in Corporate Social Responsibility. In a basis of intra firm regulation of Corporate Social Responsibility documents of international, national and corporate level are put. Examples of documents of this level can serve as the corporate Charter, the corporate code, mission statement and others, in which the specifics and strategic goals of the development of the company are reflected.

The main task of institutional framework of Corporate Social Responsibility of intra firm level is to ensure the integration of these principles into corporate strategy. Following to the principles of Corporate Social Responsibility cannot be occasional, it must be one of the key components of the strategy and business processes of the company.

For banks in Russia expectations and requirements of the government are more important than initiatives of a civil society. The main reasons of that is a fact that the population has no interest in a social bank activity and isn't active. It's obviously that credit organizations don't get enough information about their activity in area of corporate social responsibility. If banks are able to increase an information level of the society about their social responsible practices clients will have more positive perception about banks credit and financial services.

Special model of corporate social responsibility is under construction in Russia at the moment. This model is focused on a state, owners and a staff. Due to this model Russian business society creates corporate social projects according to requests of state and municipal authorities and without any legislative base for these projects realization.

\section{Conclusions}

The first hypothesis gives a possibility to make an important conclusion. A credit organization has to take into consideration interests of the main stakeholders as much as 
possible in order to support a desirable level of competitiveness and financial efficiency. And in Russian business community a policy of corporate social responsibility is becoming more and more popular because of this point of view. As the most perspective direction of theoretical research the author suggests to analyze an institutional matrix within contracts theory frames.

The second hypothesis was proved. Russian bank sector is focused on a realization of big corporate projects which match with interests of clients and staff of a credit organization. The state expectations are more defined (for example organization of Sochi Olympic Games). Therefore also it's possible to notice that tendencies of civil society organization development are becoming stronger. These tendencies provide a realization of different educational, ecological and other social projects in Russia.

Perspectives of institutionalization of corporate social responsibility in Russia are connected with legislative measures providing preferences for companies demonstrating to the society their socio-responsible behavior and also with a creation of a higher trust level between a state, a business community and civil society organizations.

Analysis of Corporate Social Responsibility practices in Russia and abroad proves that the recognition of the business principles of social responsibility first of all, a desire to create and strengthen the image of a socially responsible company, which is becoming more attractive to consumers and meaningful to investors. It is noteworthy that even the world economic crisis has not changed the positive attitude of customers to the initiatives of the business in the mainstream Corporate Social Responsibility. Corporate Social Responsibility thus links with the institutional environment in which a business community in general and the individual business organizations carry out their activities. It means that Corporate Social Responsibility can be considered as a specific socio-economic Institute, regulating interaction with stakeholders internal and external environment.

With proper inclusion of Corporate Social Responsibility in the strategic anti-crisis measures it is possible to obtain the effect of which is difficult to achieve by other way. To be able to link corporate social programs with the current economic activities, and to predict the effects of social investment, optimize non-financial risks - these are the current problems of Corporate Social Responsibility specialists of Russian companies.

Perspectives of institutionalization of corporate social responsibility in Russia are connected with legislative measures providing preferences for companies demonstrating to the society their socio-responsible behavior and also with a creation of a higher trust level between a state, a business community and civil society organizations.

\section{REFERENCES}

[1] Carroll A. B. Managing Ethically with Global Stakeholders: A Present and Future Chal- lenge, Academy of Management Executive, 2004, No 2, 114-120.

[2] Dunham L., Freeman R.E., Liedtka J. Enhancing Stakeholder Practice: A Particularized Exploration of the Com- munity, Journal of Business Ethics, 2006, No 1, 23-42.

[3] Freeman R.E., Wicks A.C., Parmar B. Stakeholder Theory and the Corporate Objective Revisited, Organization Science, 2004, No 3, 364-369.

[4] Mirvis P., Googins B. Stages of Corporate Citizenship, California Management Review, 2006, No 2, 104-126.

[5] Moon J., Crane A., Matten D. Can Corpo- rations be Citizens? Corporate Citizenship as a Metaphor for Business Participation in Society, Journal of Business Ethics, 2005, No 15, 427-451.

[6] Polischuk L.I. Corporate Social Responsibility As Government Regulation: General Analysis with an Application to Russia, Journal of the Japan Association for Com- parative Studies of Management, 2009,

[7] Tulder van R., Zwart van der A. Inter- national Business-society Management: Linking Corporate Responsibility and Globalization, New York, NY: Routledge, 2006.

[8] www.unglobalcompact.org - Website of Global Reporting Initiative (GRI).

[9] Corporate Websites of Russian Banks.

[10] IC CSR-26000-2011 «Social Responsibility of Organization. Requirements». 